\title{
OBSERVATIONS ON THE DISTRIBUTION \\ OF TABANIDAE IN THE CARIBBEAN AREA, WITH NEW RECORDS OF SPECIES FROM TRINIDAD, B.W.I. (DIPTERA)
}

\author{
By E. McC. Callan
}

Department of Zoology and Entomology, Rhodes University, Grahamstown, South Africa ${ }^{1}$

Since the appearance of Dr. J. C. Bequaert's papers on the Tabanidae of Trinidad (1940, Bull. ent. Res., 30: 447453 and 1944, Psyche, 51: 12-21), three further species have been found in that island. This brings the total to 34 species now known from Trinidad, B.W.I.

Dr. Alan Stone and Dr. G. B. Fairchild have kindly examined material of these three species. I am much indebted to Dr. Stone for the determination of Tabanus (Chlorotabanus) inanis Fabricius. To Dr. Fairchild I am very grateful for the determination of Stibasoma sulfurotaeniata Kröber var. and Fidena sp. near niveibarba Kröber and his remarks in regard to them.

An important discussion of the tabanid fauna of the Caribbean islands has been published by Bequaert (1940, Revista Ent., 11: 253-369), and Fairchild (1942, Ann. ent. Soc. Amer., $35: 441-474)$ has presented a very interesting résumé of the Tabanidae of Panama. The table below gives the number of species of Tabanidae known from various West Indian islands and adjacent parts of the Caribbean region with their approximate area in square miles.

It is evident that Trinidad, for its size, has an exceptionally rich Tabanid fauna. Indeed, Trinidad has more species of Tabanidae than any other comparable area in the Caribbean region. Further, no really intensive collecting of Tabanidae has ever been done in the island, most species

${ }^{1}$ Observations were made while the writer was on the staff of the Imperial College of Tropical Agriculture, Trinidad, B.W.I. 
collected by the late Dr. R. C. Shannon, myself and others having been taken casually in the course of other work. It seems certain that additional tabanids will be discovered in Trinidad. As Dr. Fairchild (in litt., 1951) aptly points out “. . . . a number of species are strict halophiles and should be searched for in mangrove swamps, salt marshes and along sea beaches ... others have restricted habitats in mountain forest, some being quite strictly arboreal."

$\begin{array}{lcc}\text { Country } & \begin{array}{c}\text { Approximate Area } \\ \text { in Square Miles }\end{array} & \begin{array}{c}\text { No. of Species of } \\ \text { Tabanidae Recorded }\end{array} \\ \text { Panama } & 33,800 & 106 \\ \text { Venezuela } & 346,480 & 88 \\ \text { Honduras } & 46,000 & 22 \\ \text { Cuba } & 44,000 & 12 \\ \text { Hispaniola } & 28,250 & 17 \\ \text { Puerto Rico } & 3,500 & 8 \\ \text { Jamaica } & 4,200 & 10 \\ \text { Trinidad } & 1,750 & 34 \\ \text { Antigua } & 108 & 1 \\ \text { Dominica } & 304 & 1 \\ \text { St. Vincent } & 130 & 1 \\ \text { Barbados } & 166 & 1 \\ \text { Martinique } & 380 & 0 \\ \text { Guadeloupe } & 619 & 0 \\ \text { St. Lucia } & 233 & 0 \\ \text { Grenada } & 120 & 0\end{array}$

In Venezuela a comparatively small amount of collecting has been done, and the 88 tabanids known from that country probably bear little relation to the number actually occurring there. In Panama, with an area approximately one tenth that of Venezuela, Fairchild (1942, Ann. ent. Soc. Amer., 35: 441-474; 1951, ibid., $44: 441-462$ ) has recorded 106 species from intensive collections largely confined to the central part of the Isthmus.

The Lesser Antilles are a group of small oceanic islands disposed in an arc between the north-eastern corner of Venezuela and the eastern extremity of Puerto Rico. Guadeloupe and Martinique, the largest islands of the 
archipelago, are some 619 and 380 square miles in area respectively, while some such as the Grenadines are mere islets and even rocks. Here a very interesting situation obtains in regard to the tabanid fauna. In Antigua, Dominica, St. Vincent and Barbados only a single species is known with certainty from each island (see Bequaert, 1940, Revista Ent., 11:253-369). In Martinique, Guadeloupe, St. Lucia and Grenada apparently no Tabanidae have ever been recorded.

Indubitably the Lesser Antilles have a markedly depauperate fauna, and Bequaert (loc. cit.) has suggested that the paucity of large mammals may well be the cause of the scarcity of Tabanidae. Nevertheless, it is a remarkable fact that the family appears to be completely unrepresented in several of the larger islands of the group. I have searched personally in both Grenada and St. Lucia without finding any Tabanidae. As most tabanids are haematophagous, I have also made inquiries in these islands in regard to large blood-feeding flies attacking man or livestock, but no descriptions of such flies could conceivably refer to Tabanidae.

The fauna of Trinidad and that of Grenada have quite different affinities, the former lying with the South American continent and the latter with the Antilles. This is strikingly borne out by the Tabanidae. Although Grenada is visible from the Northern Range of Trinidad on a clear day, the two islands being separated by a channel only some 90 miles wide, Trinidad has a comparatively rich Tabanid fauna comprising 34 species, all of which are also known from South America, while in Grenada the family is completely absent.

Additional Records of Tabanidae from Trinidad, B.W.I.

Tabanus (Chlorotabanus) inanis Fabricius

St. Augustine, male, 8 Jan. 1948 (D. S. Blake).

Fairchild (1940, Revista Ent., 11: 713-722) mentions that he has seen specimens from Paraguay to British Honduras and that it has also been recorded from Mexico. Dr. 
Fairchild (in litt., 1951) informs me that “. . . this species is very widespread in the neotropical region, is quite crepuscular or even nocturnal, being not rarely taken at light, and is often quite a pest of livestock."

Stibasoma sulfurotaeniata Kröber var.

St. Augustine, female, 12 Dec. 1948 (D. G. Austin).

The typical form was described from Para, Brazil and, as Dr. Fairchild (in litt., 1951) points out, the Trinidad variety lacks complete yellow bands on the third and fourth tergites, although these are present at the sides.

Fidena sp. near niveibarba Kröber

Caura Valley, 2 females, biting man, 24 June 1945 (T. S. Jones) ; Maracas Valley, 3 females, biting man, 10 August 1945 (E. McC. Callan); Caura Valley, 4 females, biting man, 9 July 1949 (E. McC. Callan).

$F$. niveibarba was described from Minas Geraes, Brazil, and the Trinidad specimens are apparently closely allied to it. In Trinidad this species is very persistent in its attack. I have been bitten by it on numerous occasions while bathing in pools in the Maracas and Caura Rivers, and it has so far been found only in these two valleys of the Northern Range. It is rather strange that this species has not been previously recorded from Trinidad. 

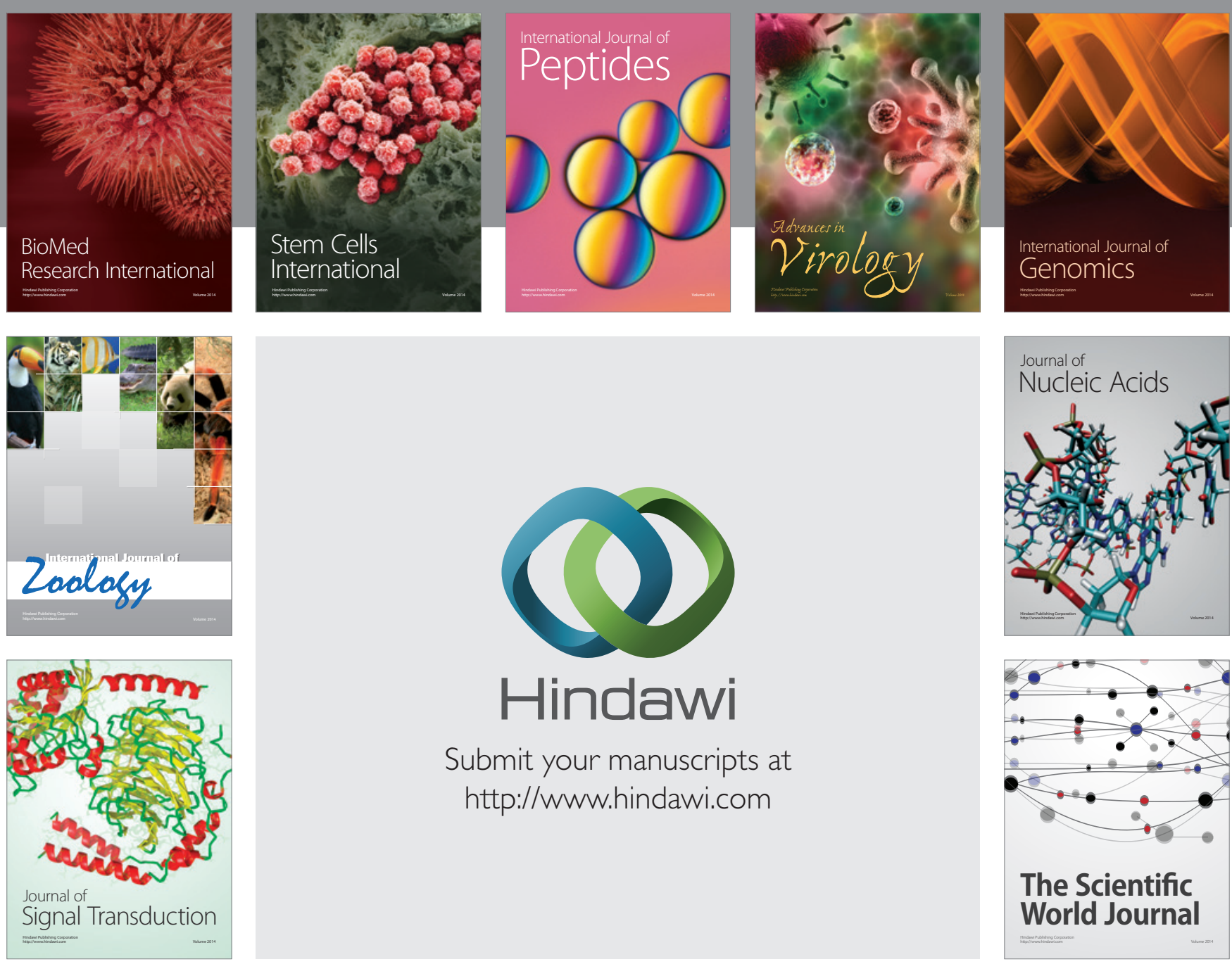

Submit your manuscripts at

http://www.hindawi.com
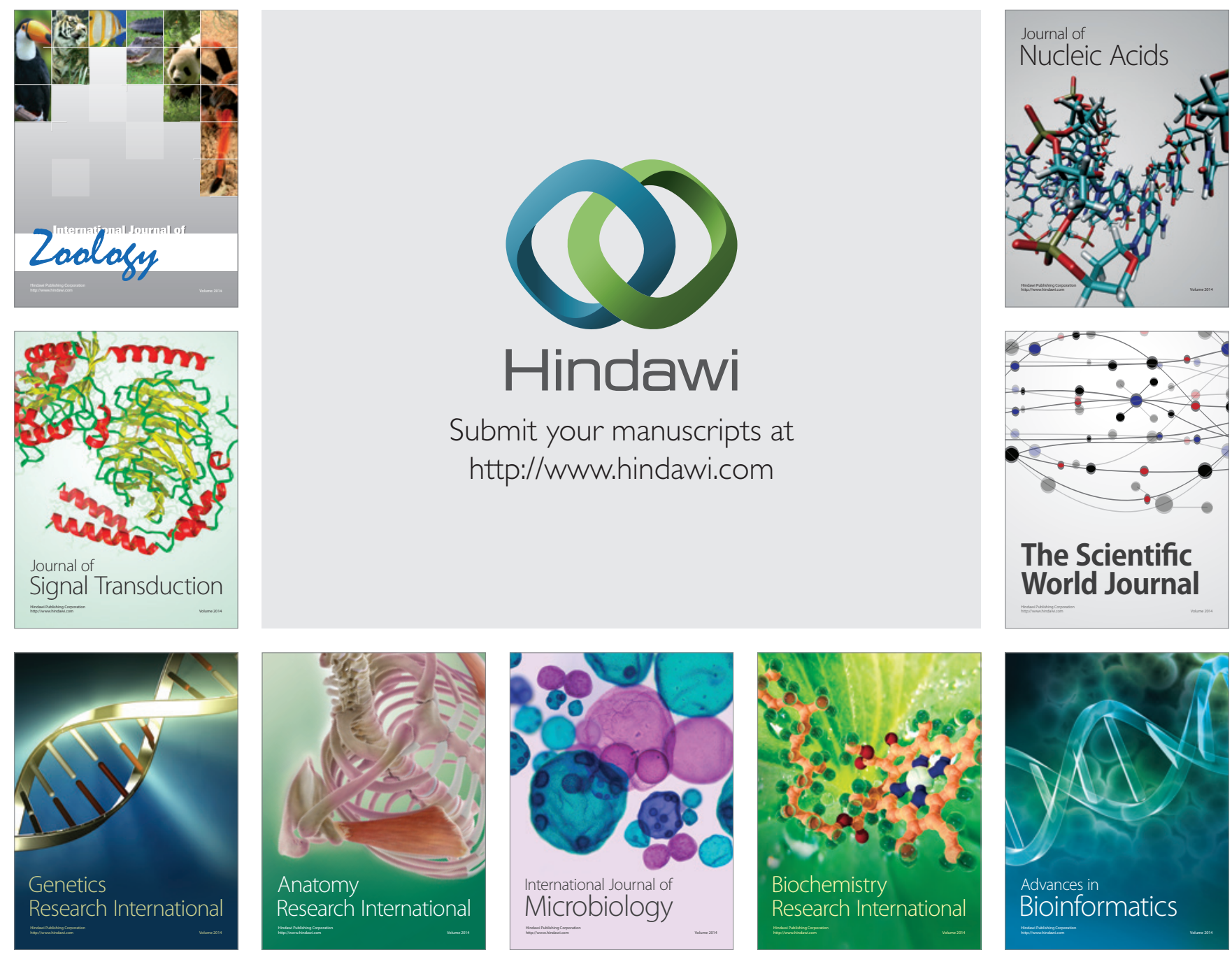

The Scientific World Journal
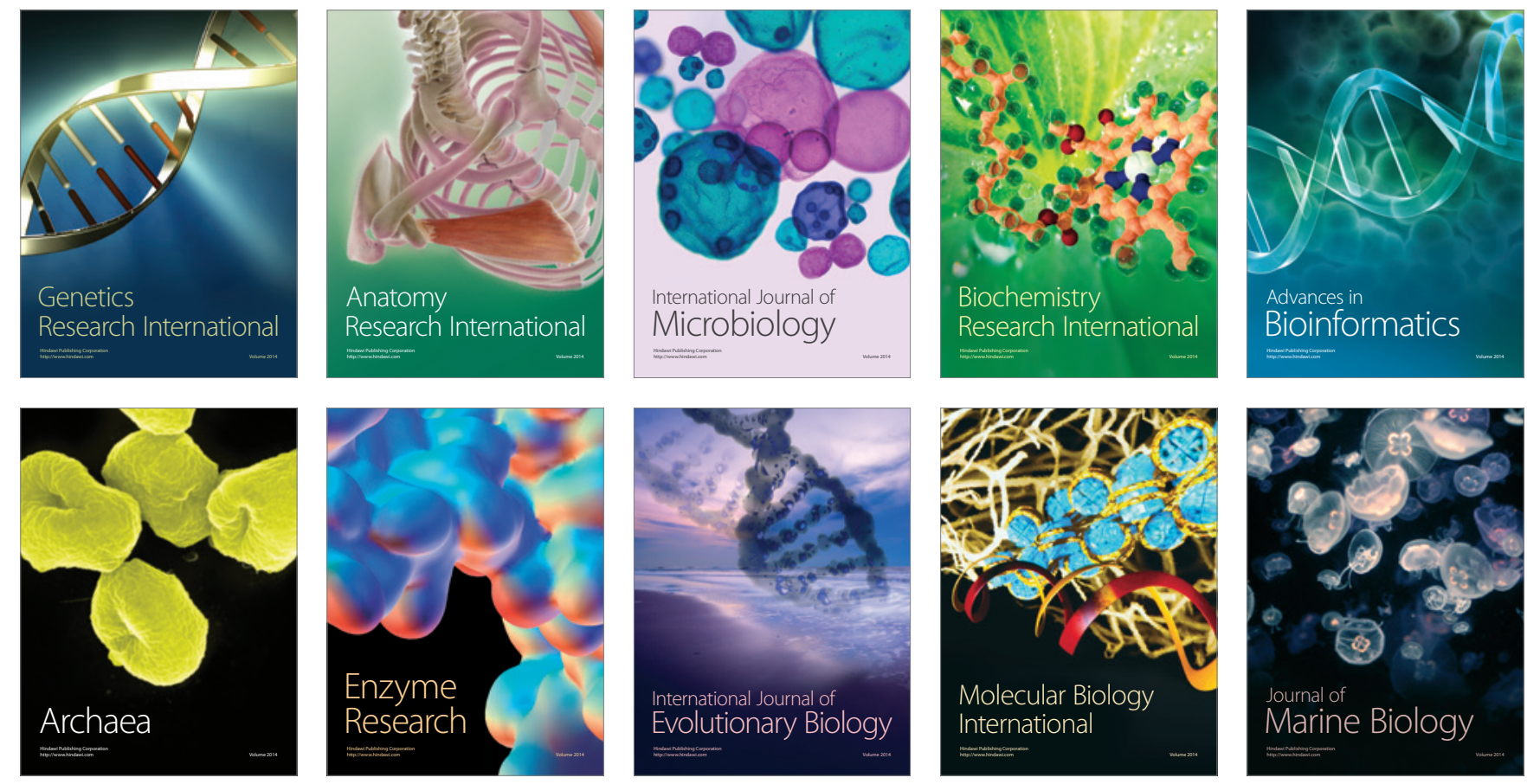